\title{
Idle gossip about validity of intralesional steroid injection in treating central giant cell granuloma
}

Ebtissam Alerraqi

Correspondence: ebtissam.erraqi@gmail.com

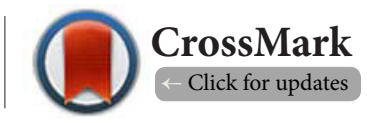

Department of Oral Pathology and Medicine, Ministry of Health, Cairo University, Egypt.

\begin{abstract}
Treating central giant cell granuloma (CGCG) via intralesional injection of steroids was proven effective in some cases. Later, clinicians have preferred this treatment modality to surgical intervention for it avoids gnathic/bony disfigurement. Advocating this non-surgical therapy, several papers and reviews have recommended putting it into action as the first line of treatment, alone or combined with other treatment options, especially in treating aggressive CGCG. Other authors have reported inaccurate information to validate this approach. This paper scrutinizes, in retrospect, the infelicities about treating CGCG via intralesional injection of steroids and concludes that intralesional steroid injection is useful ONLY in treating non-aggressive CGCG and peripheral giant cell granulomas.
\end{abstract}

Keywords: Triamcinolone, cushing's disease, giant cells, central granuloma, intralesional injection, intralesional steroid, CGCG

\section{Introduction}

Central giant cell granuloma (CGCG) of the jaw is a lesion characterized histologically by multinucleated giant cells in a background of ovoid to spindle-shaped mesenchymal cells. Since the WHO has approved the successful attempts of treating central giant cell granuloma (CGCG) via intralesional injection of steroids in some cases [1], this treatment modality was promoted to be preferred to surgical intervention for it avoids gnathic/bony disfigurement [2]. Moreover, Osterne et al., [3] have conducted a would-be "meta-analysis" of 14 papers to highlight the efficacy of using intralesional injection of corticosteroid especially intralesional triamcinolone acetonide (ITA), and to recommend its use for it is totally safe and non-invasive. Complicating matters, the duration of recruiting ITA in treating has ranged from weeks to years with determining no standards [3].

\section{Discussion}

Recently, non-surgical treatment of CGCG has been advocated by "some" clinicians with varying degrees of success. Intralesional triamcinolone, alone or combined with denosumab, or interferon, was used to reverse the osteolytic effect of CGCG [4-7]. Other clinicians, however, have reported inaccurate information about treated cases of CGCG [8-10].

This paper aims at focusing light on some glaring errors in tackling the topic of non-surgical treatment of CGCG. First, the meta-analysis study was performed using a very limited number of cases. Its recommendation of recruiting intralesional steroid injection as the mainstay treatment cannot be accepted. Second, intralesional steroid injection failed to achieve the desirable effect in several cases. Thus, the intralesional steroid injection should be only a candidate. Third, fake cases of CGCG were reported and approved [8-10]. This allowed for fake serious complications of ITA to be considered. Fourth, overlapping between CGCG and giant cell tumor (GCT) thwarts the diagnostic issues and therapeutic implications.

Tarsitano et al., [8] have reported unmatched clinical and radiological images for their treated case of CGCG. The provided panorex images of the submitted case show no trace of the orthodontic "METALLIC" wire and brackets which are present in the clinical picture. The $\mathrm{CT}$ images of the presented case do not show any metallic brackets either. At least, the initial radiographic pictures, if they belong to the described case, should have revealed such metallic brackets. This suggests that such radiograph images do not pertain to the giant-cell-containing figure.

El Hadidi $[9,10]$ has reported treating a case by injecting, TWICE WEEKLY, what is equivalent to $30 \mathrm{mg}$ of (ITA) for three months. There, the treatment was shifted to surgical removal after detecting a "cushinoid" appearance on the patient. Injecting $30 \mathrm{mg}$ of ITA resulted in a monthly accumulation of $400 \mathrm{mg}$ of ITA. According to Fredman and Tenenhaus [11], the optimal

C2016 Ebtissam Alerraqi; licensee Herbert Publications Ltd. This is an Open Access article distributed under the terms of Creative Commons Attribution License (http://creativecommons.org/licenses/by/3.0). This permits unrestricted use, distribution, and reproduction in any medium, provided the original work is properly cited. 
Ebtissam Alerraqi, Hormonal Studies 2016,

dose of ITA should not exceed $30 \mathrm{mg}$ per month in children. Thus, the authors may have iatrogenically induced an adrenal dysfunction but the patient, according to the manuscript, was never referred to any endocrinologist. The ACTH of the patient was, moreover, normal. Also, El Hadidi has turned a deaf ear to the Guidelines of the Endocrine Society's Clinical Practice in diagnosing Cushing's disease [12]. Such guidelines require basically ruling out any exogenous administration/ingestion of glucocorticoids and dictate running three screening tests to establish the diagnosis of Cushing's diseases [13]. Dang et al., [14] have used El Hadidi's case in their review. Therefore, there is no single unequivocal case of Cushing's syndrome that has resulted from treating CGCG via ITA.

Accordingly, the literature, ad hoc non-surgical treatment of CGCG, should be underpinned with much care. There is no such a magic healing effect in treating CGCG via injecting ITA for weeks especially in treating aggressive CGCG. Also, glucocorticoids, calcitonin, and osteocalcin could not differentiate between aggressive and nonaggressive central giant cell lesions of the jaws [15].

Constantly, CGCGs and GCT of bone have been overlapped. Although both lesions share histopathological dominance of osteoclalst-like giant cells, the giant cells, both in CGCG and in GCT, are not neoplastic. However, the neoplastic cells, which demonstrated high mitotic figures, are mononuclear. Moreover, CGCGs do not reveal, unlike GCT, high stromal cellularity or necrosis [16].

Cytogenetically, CGCGs do not demonstrate recurrent p. Gly34 Trp or p. Gly34 Leu mutations in the H3F3A gene [17]. However, the H3F3A mutation is evident, almost specifically, in GCT [18]. Immunohistochemically, the only salient differences between GCT and CGCG are expressed by neural and vascular markers. CGCGs demonstrate focal immunopositivity for SMA but GCT immunoreactivity for SMA is controversial. For vascular markers, CGCGs show moderate to strong expression for CD34 but GCT reveal no significant expression for the same marker. The intriguing fact about CGCG is that there is no reported metastatic CGCGs. However, GCT tends to metastasize [19].

\section{Conclusion}

To conclude, CGCGs must be differentiated from GCT. Therapeutically implicating, intralesional steroid injection is useful in treating non-aggressive central giant cell granulomas and peripheral giant cell granulomas.

\section{Competing interests}

The author declares that he has no competing interests.

Acknowledgement

I would like to send my acknowledgment to Dr Nashwa Mohammad (Ain Shams University) for her help and advices.

\section{Publication history}

EIC: Masayoshi Yamaguchi, Emory University School of Medicine, USA.

Received: 13-Apr-2016 Final Revised: 17-May-2016

Accepted: 26-May-2016 Published: 03-Jun-2016

\section{References}

1. Jundt G. Central giant cell lesion/ Simple bone cyst. In Barnes L, Eveson J, Reichart P, Sidransky D: Pathology and genetics of head and neck tumours. IARC, Lyon, France. 2005; 324-327.

2. de Lange J, van den Akker HP and van den Berg H. Central giant cell granuloma of the jaw: a review of the literature with emphasis on therapy options. Oral Surg Oral Med Oral Pathol Oral Radiol Endod. 2007; 104:603-15. | Article | PubMed

3. Osterne RL, Araujo PM, de Souza-Carvalho AC, Cavalcante RB, Sant'Ana $E$ and Nongueira RL. Intralesional corticosteroid injections in the treatment of central giant cell lesions of the jaws: a meta-analytic study. Med Oral Patol Oral Cir Bucal. 2013; 18:e226-32. | Article | PubMed Abstract | PubMed FullText

4. Oliveira LJ, Lehman LF, Gomez RS and Castro WH. Intralesional injection of corticosteroid for treatment of central giant cell lesions: case report and literature review. Oral Surgery. 2015. | Article

5. Gupta B, Stanton N, Coleman H, White C and Singh J. A novel approach to the management of a central giant cell granuloma with denosumab: A case report and review of current treatments. J Craniomaxillofac Surg. 2015; 43:1127-32. | Article | PubMed

6. Rachmiel A, Emodi O, Sabo E, Aizenbud D and Peled M. Combined treatment of aggressive central giant cell granuloma in the lower jaw. J Craniomaxillofac Surg. 2012; 40:292-7. I Article I PubMed

7. Jerkins D, Malotky M, Miremadi R and Dole M. Central Giant Cell Granuloma of the Mandible Requiring Multiple Treatment Modalities: A Case Report. J Oral Maxillofac Surg. 2016. I Article I PubMed

8. Tarsitano A, Del Corso G, Pizzigallo A and Marchetti C. Aggressive Central Giant Cell Granuloma of the Mandible Treated With Conservative Surgical Enucleation and Interferon-alpha-2a: Complete Remission With Long-Term Follow-Up. J Oral Maxillofac Surg. 2015; 73:2149-54. | Article I PubMed

9. El Hadidi YN. Cushing's disease: case report. Reactions. 2015; 1544:2268. I Article

10. El Hadidi YN, Ghanem AA and Helmy I. Injection of steroids intralesional in central giant cell granuloma cases (giant cell tumor): Is it free of systemic complications or not? A case report. Int J Surg Case Rep. 2015; 8C:166-70. | Article | PubMed Abstract | PubMed FullText

11. Fredman R and Tenenhaus M. Cushing's syndrome after intralesional triamcinolone acetonide: a systematic review of the literature and multinational survey. Burns. 2013; 39:549-57. | Article | PubMed

12. Nieman LK, Biller BM, Findling JW, Newell-Price J, Savage MO, Stewart PM and Montori VM. The diagnosis of Cushing's syndrome: an Endocrine Society Clinical Practice Guideline. J Clin Endocrinol Metab. 2008; 93:1526-40. | Article | PubMed Abstract | PubMed FullText

13. Alerraqi E. Commentary on: Injection of Steroids Intralesional in Central Giant Cell Granuloma Cases (Giant Cell Tumor): Is it Free of Systemic Complications or Not? J Steroids Hormon Sci. 2016; 7:e117.

14. Pham Dang N, Longeac M, Picard M, Devoize L and Barthelemy I. [Central giant cell granuloma in children: Presentation of different therapeutic options]. Rev Stomatol Chir Maxillofac Chir Orale. 2016. | Article | $\underline{\text { PubMed }}$

15. Martins AF, Souza PO, Rege IC, Morais MO and Mendonca EF. Glucocorticoids, calcitonin, and osteocalcin cannot differentiate between aggressive and nonaggressive central giant cell lesions of the jaws. Oral Surg Oral Med Oral Pathol Oral Radiol. 2015; 120:386-95. | Article I PubMed

16. Saxena CC, Safaya R, Kawatra Madan N, Khan SA and Iyer VK. Histopathological, immunohistochemical, and image analytic parameters characterizing the stromal component in primary and recurrent giant cell tumor of bone. J Clin Orthop Trauma. 2016; 7:10914. I Article I PubMed

17. Gomes CC, Diniz MG, Amaral FR, Antonini Guimaraes BV and Gomez RS. 
Ebtissam Alerraqi, Hormonal Studies 2016,

http://www.hoajonline.com/journals/pdf/2052-8000-4-1.pdf

The highly prevalent H3F3A mutation in giant cell tumours of bone is not shared by sporadic central giant cell lesion of the jaws. Oral Surg Oral Med Oral Pathol Oral Radiol. 2014; 118:583-5. | Article | PubMed

18. Behjati S, Tarpey PS, Presneau N, Scheipl S, Pillay N, Van Loo P, Wedge DC, Cooke SL, Gundem G, Davies H, Nik-Zainal S, Martin S, McLaren S, Goody V, Robinson B and Butler A et al. Distinct H3F3A and H3F3B driver mutations define chondroblastoma and giant cell tumor of bone. Nat Genet. 2013; 45:1479-82. | Article | PubMed Abstract | PubMed FullText

19. Al Sheddi MA, Mosadomi HA and Al Dayel F H. Central giant cell granuloma of the jaws and giant cell tumor of long bones: $A$ clinicopathological, cytometric and immunohistochemical comparative study. Saudi J Oral Sci. 2014; 1:47-53. | Article

\section{Citation:}

Alerraqi E. Idle gossip about validity of intralesional steroid injection in treating central giant cell granuloma. Horm Stud. 2016; 4:1.

http://dx.doi.org/10.7243/2052-8000-4-1 